\title{
Corrigenda \\ Opportunities and Challenges of Psychiatric Drug Discovery: Roles for Scientists in Academic, Industry, and Government Settings
}

P Jeffrey Conn and Bryan L Roth

Neuropsychopharmacology (2008) 33, 2300; doi:I0.1038/npp.2008.83; published online 4 June 2008

Correction to: Neuropsychopharmacology advance online publication 23 January 2008. doi:10.1038/sj.npp.1301638

The authors wish to declare that this work was commissioned by the Institute of Medicine. The responsibility for the content of this article rests with the authors and does not necessarily represent the views of the Institute of Medicine or its committees and convening bodies.

\section{Novel Drugs and Therapeutic Targets for Severe Mood Disorders}

Sanjay J Mathew, Husseini K Manji and Dennis S Charney

Neuropsychopharmacology (2008) 33, 2300; doi:I0.1038/npp.2008.84; published online 4 June 2008
Correction to: Neuropsychopharmacology advance online publication 2 January 2008. doi:10.1038/sj.npp.1301652

The authors wish to declare that this work was commissioned by the Institute of Medicine. The respon- sibility for the content of this article rests with the authors and does not necessarily represent the views of the Institute of Medicine or its committees and convening bodies. 